\author{
Habitus Aquatica \\ Journal of Aquatic Resources and Fisheries Management \\ Journal homepage: \\ http://journal.ipb.ac.id/index.php/habitusaquatica
}

\title{
Identifikasi Karakterstik Molekuler Gen 16S rRNA Parsial pada Paus Sperma (Physeter macrocephalus Linnaeus, 1758)
}

\section{Molecular Characteristic Identification of Partial 16S rRNA Genes of Sperm Whales (Physeter macrocephalus Linnaeus, 1758)}

\author{
Mohammad Mukhlis Kamal ${ }^{1, *}$, Nurlisa A Butet ${ }^{1}$, Endah Sri Rahayu ${ }^{1}$, Agus Alim Hakim ${ }^{1}$ \\ ${ }^{I}$ Departemen Manajemen Sumbedaya Perairan, Fakultas Perikanan dan Ilmu Kelautan, Institut Pertanian Bogor, Jl. \\ Agatis Kampus IPB Dramaga, Bogor, Indonesia
}

Received 11 November $2020 \quad$ Received in revised 20 Desember 2020 Accepted 29 Januari 2021

\section{ABSTRAK}

Paus sperma (Physeter macrocephalus) merupakan salah satu mamalia laut yang dikategorikan dalam status vulnerable pada IUCN dan status Appendix I pada CITES. Identitas asli dari paus sperma secara molekuler dapat ditelusuri. Penelitian ini bertujuan untuk mengidentifikasi karakteristik molekuler paus sperma (P. macrocephalus) berdasarkan gen 16s rRNA parsial. Tiga contoh jaringan paus sperma yang dianalisis berasal dari perairan Laut Sawu, Nusa Tenggara Timur. Hasil identifikasi berdasarkan sekuen basa nukleotida gen parsial 16S rRNA menunjukkan bahwa ketiga contoh memiliki kemiripan dengan Physeter catodon sebesar 99\%, dimana P. catodon merupakan sinonim dari $P$. macrocephalus. Pensejajaran sekuen nukleotida dengan outgroup (Balaenoptera physalus dan Balaena mysticetus) didapatkan nilai jarak genetik ketiga contoh dengan outgroup berkisar antara 0,0093-0,0726. Selain itu, didapatkan 25 nukleotida spesifik P. macrocephalus yang mampu membedakan dari spesies outgroup. Penelitian ini mampu memvalidasi spesies $P$. macrocephalus berdasarkan gen 16S rRNA dan dapat dijadikan sebagai marka molekuler yang kuat untuk identifikasi P. macrocephalus.

Kata kunci: 16S rRNA, Laut Lawu, paus sperma, Physeter macrocephalus

\begin{abstract}
Sperm whale (Physeter macrocephalus) is one of the marine mammals that is categorized as vulnerable on IUCN and Appendix I status on CITES. The aunthentic identity of the sperm whale can be traced molecularly. This study aims to identify the molecular characteristics of the sperm whale ( . macrocephalus) based on the partial 16s rRNA gene. Three samples of sperm whale tissue analyzed came from the Lawu Sea Waters, East Nusa Tenggara. The identification results based on the nucleotide base sequence show that the three samples have 99\% similarity to Physeter catodon, where P. catodon is a synonym for P. macrocephalus. The alignment of the nucleotide sequences with the outgroup (Balaenoptera physalus and Balaena mysticetus) obtained the genetic distance values of the three samples with outgroups ranging from 0.0093-0.0726. In addition, there were 25 specific nucleotides of $\underline{P}$. macrocephalus that were able to differentiate from outgroup species. This study is success to validate $\underline{P}$. macrocephalus species based on the $16 S$ rRNA gene and can be used as a strong molecular marker for the identification of $\underline{\text { P. macrocephalus. }}$
\end{abstract}

Keywords: 16S rRNA, Lawu Sea, sperm whale, Physeter macrocephalus 


\section{Pendahuluan}

Paus sperma (Physeter macrocephalus) adalah salah satu mamalia laut yang dikategorikan ke dalam kelompok cetacean. Menurut Yusron (2012), Cetacea merupakan mamalia laut memiliki habitat air dan sepenuhnya menyesuaikan diri lingkungan perairan, sebagai contoh yaitu paus dan lumba-lumba. Sebanyak 86 spesies paus dan lumba-lumba yang terdapat di dunia, 31 spesies ditemukan di perairan Indonesia (Tomascik et al. 1997). Beberapa penelitian menyebutkan bahwa wilayah Indonesia sebagai tempat ditemukan atau menjadi jalur migrasi bagi kelompok cetacean yatu di perairan Flores (Setiawan 2004), Selat Makassar (Kreb dan Budiono 2005), Sulawesi Utara, Pulau Komodo (APEX Lingkungan 2011), Raja Ampat (Lazuardi et al. 2011), Lamalera (Yusron 2012), dan Laut Sawu (Ramadhan 2015).

Paus sperma dikategorikan ke dalam Odontoceti (paus bergigi) dengan jumlah populasi di alam mengalami penurunan. Penurunan populasi tersebut disebabkan oleh faktor-faktor seperti predator, perubahan lingkungan, dan penangkapan. Kegiatan penangkapan oleh manusia sering kali dilakukan dengan alasan pada pemenuhan kebutuhan hidup sehari-hari. Salah satu daerah pemanfaatan $P$. macrocephalus di Indonesia yaitu perairan Laut Sawu yang dilakukan oleh suku Lamalera. Penangkapan ini dibuktikan dengan terdapatnya komunitas tradisional pemburu ikan dan mamalia di laut Lamalera yang melakukan perburuan atau penangkapan pada ikan-ikan besar. Kegiatan perburuan atau penangkapan ini telah dinyatakan legal oleh International Whaling Commission (IWC) dan Undang-Undang Nomor 45 Tahun 2009 (Ramadhan 2015). Menurut Desrianti (2011), perburuan terhadap paus sperma tersebut merupakan budaya dasar dan menjadi landasan bagi berdirinya suatu sistem sosiokultur yang utuh di Lamalera.

Paus sperma adalah mamalia kelompok migratory species yang memiliki daerah jelajah yang luas dan keberadaan di suatu daerah dapat terjadi pencampuran subpopulasi terutama pada daerah feeding ground maupun spawning ground (Rice 1989). Terjadinya pencampuran populasi menyebabkan penelusuran keaslian spesies tersebut sulit ditentukan. Identifikasi berdasarkan marka molekuler dapat memfasilitasi penelusuran identitas asli dari $P$. macrocephalus. Salah satu Teknik identifikasi molekuler yaitu DNA barcoding yang diperkenalkan oleh Hebert et al. (2003). Teknik DNA barcoding adalah pendekatan molekuler yang dapat mengidentifikasi spesies secara lebih akurat (Tudge 2000). Proses identifikasi berdasarkan mrka molekuler dengan teknik DNA barcoding dengan menggunakan sebagian kecil dari tubuh biota mampu memberikan hasil dengan tingkat ketelitian yang tinggi.

DNA mitokondria memiliki beberapa kelebihan dibandingkan dengan DNA inti. Tingkat evolusi lebih cepat, berukuran lebih kecil, dan terdapat dalam jumlah copy tinggi pada DNA mitokondria dibandingkan dengan DNA inti, sehingga DNA mitokondria mudah dalam proses isolasi dan purifikasi (Jusuf 2001). Salah satu gen penanda yang berasal dari DNA mitokondria yaitu gen 16S rRNA. Gen 16S rRNA juga digunakan dalam proses identifikasi spesies akuatik (Mitani et al. 2009). Beberapa penelitian mengenai paus sperma (P. macrocephalus) telah dilakukan di Indonesia. Namun, penelitian genetik berdasarkan gen 16S rRNA belum pernah dilakukan sebelumnya. Penelitian ini bertujuan untuk mengidentifikasi karakteristik molekuler paus sperma ( $P$. macrocephalus) berdasarkan gen parsial 16s rRNA. Hasil DNA barcoding dari penelitian ini dapat digunakan sebagai informasi identitas molekuler pada spesies $P$. macrocephalus.

\section{Metode}

\subsection{Waktu dan Lokasi}

Contoh jaringan paus sperma merupakan koleksi contoh yang diambil dari perairan Laut Sawu, Nusa Tenggara Timur (Gambar 1). Analisis laboratorium dilakukan di Laboratorium Biologi Molekuler Akuatik, Departemen Manajemen Sumberdaya Perairan, FPIK, IPB pada bulan Oktober 2015 hingga Februari 2016. 


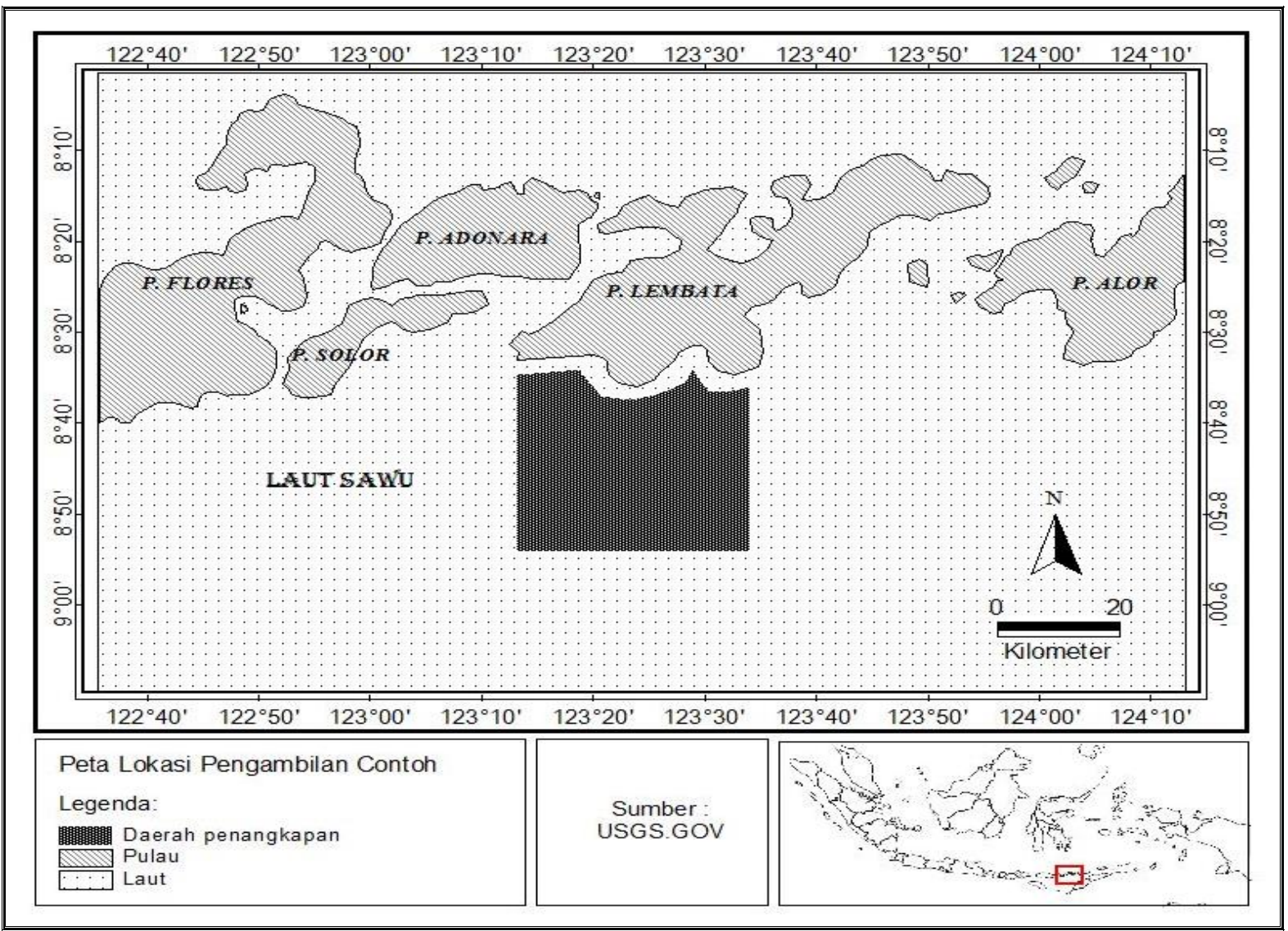

Gambar 1. Lokasi pengambilan contoh paus sperma di perairan Laut Sawu, Nusa Tenggara Timur.

\subsection{Prosedur Penelitian}

\subsubsection{Pengambilan Contoh}

Tiga contoh paus sperma yang diambil berupa jaringan yang telah dimasukkan ke dalam botol sampel berukuran $100 \mathrm{ml}$ dan diawetkan dengan alkohol 96\%. Contoh tersebut kemudian dibawa ke Laboratorium Biologi Molekuler Akuatik untuk analisis molekuler. Spesies contoh paus sperma yang digunakan merupakan koleksi laboratorium yang berasal dari Nusa Tenggara Timur yang diambil pada tahun 2014. Contoh paus telah diidentifikasi sebagai Physeter macrocephalus yang tertera pada label botol sampel.

\subsubsection{Analisis Laboratorium}

Contoh ditimbang sebanyak $40 \mathrm{mg}$ dan dilakukan preparasi untuk menghilangkan pengaruh pengawet alkohol 96\%. Preparasi dilakukan melalui pencucian dengan aquades sebanyak 5 kali kemudian dikeringkan untuk menghilangkan kandungan alkohol. Contoh dimasukkan ke dalam microtube dan dilakukan proses isolasi dan ekstraksi DNA menggunakan kit komersil (Gene Aid) dengan prosedur mengikuti manual pabrik.

DNA total yang didapatkan dari proses isolasi dan ekstrasi digunakan sebagai cetakan dalam proses amplifikasi fragmen DNA gen 16S rRNA dengan menggunakan teknik PCR (Polymerase Chain Reaction). Komposisi PCR terdiri dari $\mathrm{ddH}_{2} \mathrm{O}$, Taq dari kit komersial Kapa Extra Hot Start, primer, dan cetakan DNA. Primer yang digunakan berupa primer universal untuk beberapa biota akuatik yang didesain oleh Butet (2013, unpublish data). Proses amplifikasi gen 16S rRNA dilakukan selama 35 siklus dengan rincian proses disajikan pada Tabel 1.

Produk PCR uji kualitasnya melalui elektroforesis dengan menggunakan gel agarosa 1,2\% dan divisualisasi menggunakan mesin ultraviolet. Produk PCR yang memiliki kualitas baik dilanjutkan pada tahap sekuensing untuk didapatkan sekuen basa nukleotida. Sekuensing dilakukan dengan metode Sanger (1977) dengan mengirimkan produk PCR ke perusahaan jasa sekuensing yang berada di Malaysia. 
Tabel 1. Tahapan amplifikasi gen 16S rRNA.

\begin{tabular}{lccc}
\hline \multicolumn{1}{c}{ Tahap } & Suhu $\left({ }^{\circ} \mathrm{C}\right)$ & Waktu & Siklus \\
\hline predenaturasi & 94 & 3 menit & \\
denaturasi & 94 & 45 detik & \\
annealing & 46 & 1 menit & 35 \\
elongasi & 72 & 1 menit & \\
pascaelongasi & 72 & 5 menit & \\
penyimpanan & 15 & 10 menit & \\
\hline
\end{tabular}

\subsubsection{Analisis Bioinformatika}

Hasil sekuensing diedit untuk didapatkan urutan basa nukleotida dan divalidasi dengan cara mengunggah pada situs NCBI (National Center for Biotechnology Information) pada menu Basic Local Alignment Search Toolnucleotide (BLASTn). Sekuen nukleotida disejajarkan dengan menggunakan metode Clustal W. Jarak genetik dihitung dengan menggunakan metode pairwise distance. Pohon filogeni direkontruksi menggunakan metode bootstrapped Neighbour-Joinning (NJ) dengan 1000 kali pengulangan. Pensejajaran nukleotida, perhitungan jarak genetik, dan rekontruksi pohon filogeni dilakukan dengan software MEGA 5.2 (Tamura et al. 2011).

\section{Hasil dan Pembahasan}

\subsection{Hasil}

Hasil amplifikasi dari ketiga contoh telah ditunjukkan pada Gambar 2 dan didapatkan kualitas produk PCR yang baik. Urutan nukleotida memiliki panjang berkisar antara 500-700 bp.

Hasil sekuensing gen $16 \mathrm{~S}$ rRNA diperoleh ukuran basa pada masing-masing sampel sebesar 572, 574, dan 580 bp. Validasi spesies berdasarkan gen parsial 16S rRNA melalui pengunggahan pada situs NCBI didapat bahwa ketiga contoh Physeter macrocephalus memiliki kemiripan sebesar 99\% dengan Physeter catodon. Urutan basa nukleotida contoh disejajarkan dengan outgroup berupa Balaenoptera physalus dan Balaena mysticetus yang berasal dari GenBank. Hasil pensejajaran diperoleh didapatkan nilai variable sebesar $8,70 \%$ (47/540), conserve sebesar 91,30\% (493/540), dan singleton sebesar 4,63\% (25/540).

Perhitungan jarak genetik didapatkan bahwa jarak genetik $P$. macrocephalus dengan Balaenoptera physalus dan Balaena mysticetus berkisar antara 0,0093-0,0726. Matriks hasil jarak genetik disajikan pada Tabel 2.

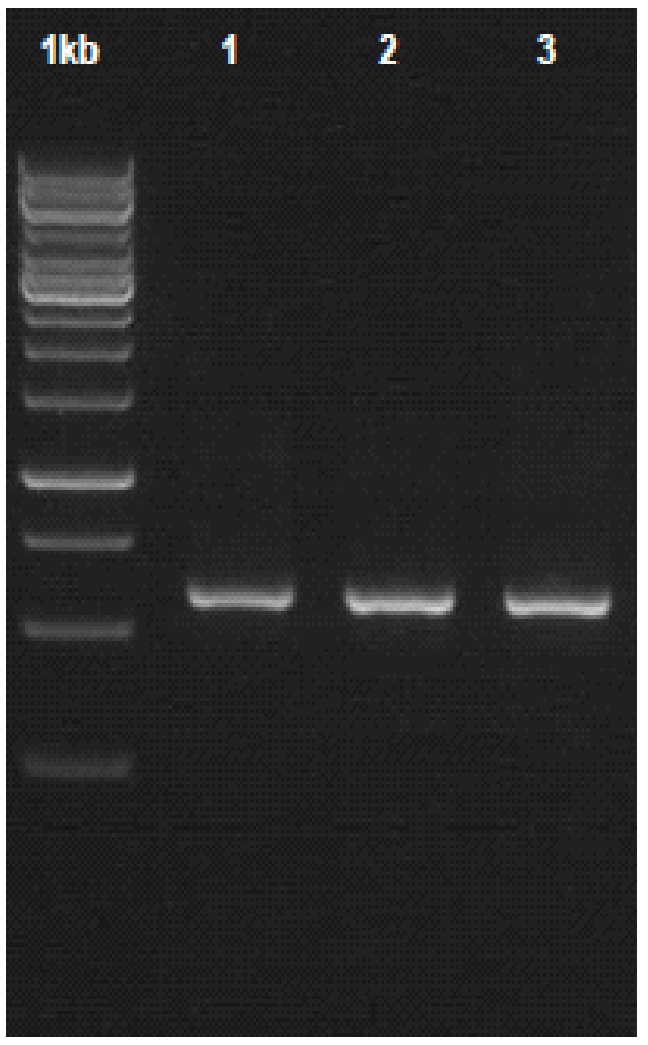

Gambar 2. Visualisasi gen 16S rRNA ketiga contoh pada gel agarosa $1 \%$.

Jarak genetik dijadikan sebagai data untuk analisis kekerabatan melalui pohon filogeni. Pohon filogeni menunjukkan tingkat kekerabatan antara ingroup dan outgroup pada $P$. macrocephalus (contoh 1, 2, dan 3) dengan Balaena mysticetus and Balaenoptera physalus (Gambar 3).

Situs nukleotida spesifik dari gen 16S rRNA contoh $P$. macrocephalus didapatkan setelah penyejajaran dengan Balaena mysticetus dan Balaenoptera physalus. Terdapat 25 situs nukleotida spesifik yang merupakan basa nukleotida penciri yang menjadi pembeda dengan spesies lain (Tabel 3) 
Tabel 2. Matriks jarak genetik P. Macrocephalus, Balaenoptera physalus, dan Balaena mysticetus berdasarkan gen $16 \mathrm{~S}$ rRNA dengan metode pairwise distance.

\begin{tabular}{|c|c|c|c|c|}
\hline Spesies & $\begin{array}{c}\text { P. macrocephalus } \\
1\end{array}$ & $\begin{array}{l}\text { P. macrocephalus } \\
2\end{array}$ & $\begin{array}{l}\text { P. macrocephalus } \\
3\end{array}$ & $\begin{array}{c}\text { Balaenoptera physalus } \\
\text { (KC572835.1) }\end{array}$ \\
\hline \multicolumn{5}{|l|}{ P. macrocephalus 1} \\
\hline P. macrocephalus 2 & 0,0093 & & & \\
\hline P. macrocephalus 3 & 0,0149 & 0,0168 & & \\
\hline $\begin{array}{l}\text { Balaenoptera physalus } \\
\text { (KC572835.1) }\end{array}$ & 0,0652 & 0,0596 & 0,0726 & \\
\hline $\begin{array}{l}\text { Balaena mysticetus } \\
\text { (AP006472.1) }\end{array}$ & 0,0559 & 0,0503 & 0,0633 & 0,0354 \\
\hline
\end{tabular}
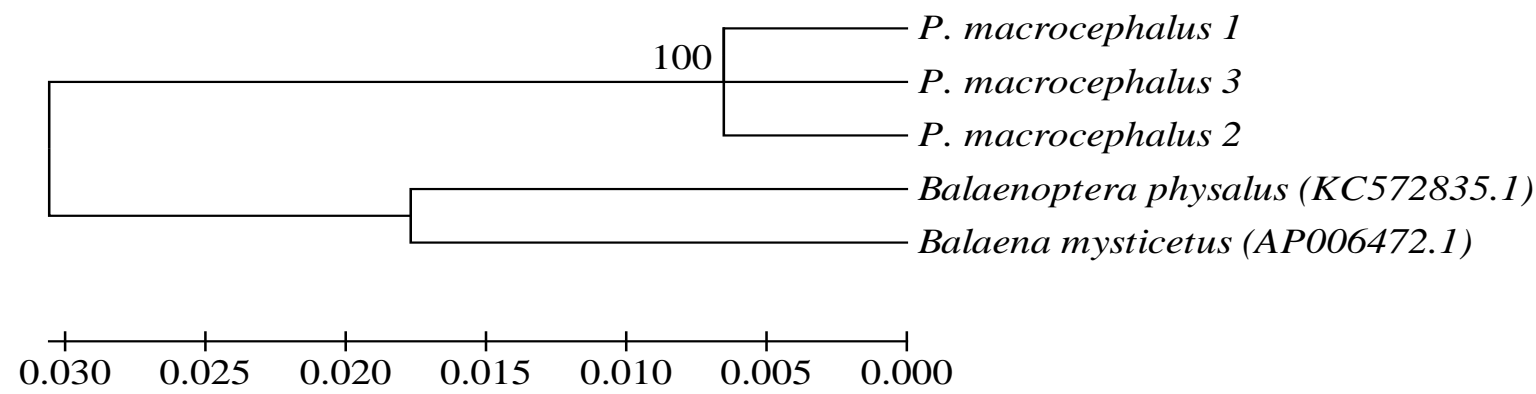

Gambar 3. Konstruksi pohon filogeni P. macrocephalus, Balaena mysticetus, dan Balaenoptera physalus berdasarkan gen 16S rRNA.

Tabel 3. Situs nukleotida spesifik dari gen 16S rRNA.

\begin{tabular}{|c|c|c|c|c|c|c|c|c|c|c|c|c|c|}
\hline \multirow[b]{2}{*}{ Spesies } & \multicolumn{13}{|c|}{ Situs nukleotida ke- } \\
\hline & 30 & 31 & 92 & $\begin{array}{c}15 \\
9\end{array}$ & $\begin{array}{c}17 \\
4\end{array}$ & $\begin{array}{c}18 \\
0\end{array}$ & $\begin{array}{c}21 \\
1\end{array}$ & $\begin{array}{c}21 \\
2\end{array}$ & $\begin{array}{c}23 \\
0\end{array}$ & $\begin{array}{c}24 \\
0\end{array}$ & $\begin{array}{c}26 \\
3\end{array}$ & $\begin{array}{c}26 \\
4\end{array}$ & $\begin{array}{c}26 \\
9\end{array}$ \\
\hline $\begin{array}{l}\text { Balaenoptera physalus } \\
\text { (KC572835.1) }\end{array}$ & $\mathrm{T}$ & $\mathrm{C}$ & G & $\mathrm{T}$ & A & $\mathrm{C}$ & $\mathrm{C}$ & A & $\mathrm{C}$ & $\mathrm{T}$ & $\mathrm{C}$ & $\mathrm{C}$ & $\mathrm{T}$ \\
\hline P. macrocephalus 1 & $\mathbf{T}$ & $\mathbf{A}$ & $\mathbf{A}$ & $\mathrm{C}$ & G & $\mathbf{C}$ & $\mathbf{C}$ & $\mathbf{A}$ & $\mathbf{C}$ & $\mathbf{C}$ & $\mathbf{A}$ & $\mathbf{C}$ & G \\
\hline P. macrocephalus 2 & $\mathbf{T}$ & $\mathbf{A}$ & $\mathbf{A}$ & $\mathrm{C}$ & G & C & C & $\mathbf{A}$ & $\mathbf{C}$ & $\mathbf{C}$ & $\mathbf{A}$ & $\mathbf{C}$ & G \\
\hline P. macrocephalus 3 & $\mathbf{T}$ & $\mathbf{A}$ & $\mathbf{A}$ & $\mathrm{C}$ & G & $\mathrm{C}$ & $\mathbf{T}$ & $\mathrm{C}$ & $\mathbf{C}$ & $\mathbf{C}$ & $\mathbf{A}$ & $\mathbf{C}$ & G \\
\hline Balaena mysticetus (AP006472.1) & $\mathrm{C}$ & $\mathrm{A}$ & $\mathrm{A}$ & $\mathrm{C}$ & $\mathrm{G}$ & $\mathrm{T}$ & $\mathrm{C}$ & $\mathrm{A}$ & $\mathrm{T}$ & $\mathrm{C}$ & $\mathrm{T}$ & $\mathrm{T}$ & $\mathrm{A}$ \\
\hline \multirow[b]{2}{*}{ Spesies } & \multicolumn{12}{|c|}{ Situs nukleotida ke- } & \\
\hline & $\begin{array}{c}27 \\
4\end{array}$ & $\begin{array}{c}30 \\
1\end{array}$ & $\begin{array}{c}30 \\
3\end{array}$ & $\begin{array}{c}30 \\
4\end{array}$ & $\begin{array}{c}33 \\
0\end{array}$ & $\begin{array}{c}33 \\
2\end{array}$ & $\begin{array}{c}35 \\
1\end{array}$ & $\begin{array}{c}35 \\
3\end{array}$ & $\begin{array}{c}37 \\
6\end{array}$ & $\begin{array}{c}38 \\
8\end{array}$ & $\begin{array}{c}49 \\
2\end{array}$ & $\begin{array}{c}51 \\
2\end{array}$ & \\
\hline $\begin{array}{l}\text { Balaenoptera physalus } \\
\text { (KC572835.1) }\end{array}$ & $\mathrm{T}$ & G & G & $\mathrm{T}$ & A & $\mathrm{T}$ & $\mathrm{T}$ & $\mathrm{C}$ & $\mathrm{C}$ & G & $\mathrm{T}$ & $\mathrm{T}$ & \\
\hline P. macrocephalus 1 & $\mathbf{T}$ & G & $\mathbf{A}$ & C & G & C & C & $\mathbf{T}$ & C & G & C & $\mathbf{T}$ & \\
\hline P. macrocephalus 2 & $\mathbf{T}$ & $\mathbf{G}$ & $\mathbf{G}$ & C & G & C & C & $\mathbf{T}$ & C & $\mathbf{G}$ & C & $\mathbf{T}$ & \\
\hline P. macrocephalus 3 & $\mathbf{T}$ & $\mathbf{A}$ & G & $\mathbf{C}$ & G & $\mathrm{C}$ & $\mathrm{C}$ & $\mathbf{T}$ & $\mathbf{C}$ & $\mathbf{A}$ & $\mathrm{C}$ & $\mathbf{C}$ & \\
\hline Balaena mysticetus (AP006472.1) & $\mathrm{C}$ & $\mathrm{G}$ & $\mathrm{G}$ & $\mathrm{C}$ & $\mathrm{G}$ & $\mathrm{C}$ & $\mathrm{C}$ & $\mathrm{T}$ & $\mathrm{T}$ & $\mathrm{G}$ & $\mathrm{C}$ & $\mathrm{T}$ & \\
\hline
\end{tabular}

\subsection{Pembahasan}

Identifikasi

P. macrocephalus

berdasarkan gen parsial $16 \mathrm{~S}$ rRNA menggunakan BLASTn didapatkan nilai $99 \%$ kemiripan dengan $P$. catodon. Hal ini menguatkan taksonomi berdasarkan hasil identifikasi secara morfologi, dimana $P$. catodon merupakan sinonim dari $P$. macrocephalus. Berdasarkan prinsip revisionis pertama, nama $P$. macrocephalus lebih diutamakan sebagai nama resmi paus sperma (Husson dan Holthuis 1974). Kemiripan sebesar 99\% tersebut bahwa $P$. macrocephalus dari lokasi penelitian memiliki kemiripan dengan paus sperma yang berasal dari berbagai belahan dunia. Beberapa wilayah tersebut yaitu Islandia (Arnason et al. 2000), Oregon, dan Selandia 
Baru (Alexander et al. 2012). Islandia mewakili daerah perairan Samudera Atlantik pada bagian utara; Oregon mewakili daerah perairan Samudera Pasifik; Selandia Baru dan Indonesia (pada penelitian ini) mewaliki daerah perairan Samudera Hindia. Penemuan speises ini pada beberapa daerah menjadi salah satu bukti bahwa paus perma ( $P$. macrocephalus) memiliki daerah jelajah yang luas sehingga dapat disebut sebagai highly migratory species.

Urutan basa nukleotida dari $P$. macrocephalus disejajarkan dengan Balaena mysticetus dan Balaenoptera physalus yang diperoleh dari GenBank. Nilai jarak genetik outgroup antara ketiga contoh $P$. macrocephalus dengan Balaenoptera physalus dan Balaena mysticetus memiliki nilai yang lebih tinggi dari ingroup. Hal tersebut menunjukkan bahwa teknik molekuler berdasarkan marka 16S rRNA mampu mengidentifikasi adanya perbedaan antara $P$. macrocephalus dengan spesiesspesies yang dibandingkan. Konstruksi pohon filogeni menunjukkan pemisahan yang jelas antara famili Balaenidae, Balaenopteridae, dan Physeteridae. Pemisahan tersebut terjadi disebabkan oleh keberadaan situs nukleotida spesifik. Situs tersebut menandakan adanya pembeda susunan basa nukleotida dari ketiga contoh yang diteliti dengan spesies yang dibandingkan yaitu (Balaena mysticetus dan Balaenoptera physalus). Berdasarkan gen parsial 16S rRNA, situs nukleotida spesifik yang ditemukan sebanyak 25 yang mengindikasikan terjadi evolusi yang spesifik terhadap P. macrocephalus.

Paus sperma ( $P$. macrocephalus) dikategorikan sebagai salah satu mamalia laut dilindungi karena semakin berkurang keberadaannya di alam. Hal tersebut ditunjukkan dengan pernyataan dari IUCN (International Union for Conservation of Nature and Natural Resources) (2015) bahwa $P$. macrocephalus masuk dalam kategori rentan atau "Vulnerable". Notarbartolo et al. (2012) menambahkan bahwa spesies tersebut sudah masuk dalam kategori genting atau "Endangered" pada subpopulasi Mediteranian. Upaya perlindungan terhadap spesies ini dari kegiatan perdagangan yaitu telah dipertegas pada kategori Appendiks I oleh CITES (The Convention on International Trade in Endangered Species of Wild Fauna and Flora). Secara hukum, P. macrocephalus telah dilarang diperjual belikan dengan segala bentuk perdagangan internasional.

Paus sperma merupakan spesies tunggal yang memiliki resiko tinggi terhadap kepunahan, sehingga perlu adanya upaya perlindungan melalui konservasi agar keberadaanya tetap lestari. Upaya perlindungan pada paus sperma perlu memerhatikan semua aspek yang berkaitan dengan spesies itu sendiri. Saat ini secara umum di dunia telah dilakukan upaya perlindungan serta pengelolaan $P$. macrocephalus. Upaya perlindungan dan pengelolaan tersebut meliputi monitoring marine conservation (Creese dan Cole 1995), marine protected areas (Hoyt 2005; Gormley 2012), pengamatan terhadap kelimpahan (Taylor et al. 2007), dan lain sebagainya. Sedangkan di Indonesia, upaya perlindungan dan pengelolaan terhadap $P$. macrocephalus masih belum optimal. Hal ini dimungkinkan karena masih terbatasnya informasi yang berkaitan dengan $P$. macrocephalus serta informasi pendukung lainnya.

Teknik molekuler saat ini telah menjadi bagian dari studi berbasis sistematika dan konservasi (Hillis et al. 1996). Menurut Trivedi et al. (2015), DNA barcoding memiliki peran dan berpengaruh secara signifikan pada upaya konservasi sumberdaya alam hayati di dalam ekosistem laut yang luas dan beragam. Identifikasi molekuler terhadap paus sperma pada penelitian ini dapat dijadikan sebagai salah satu acuan dasar dalam upaya perlindungan dan menjaga kelestarian $P$. macrocephalus melalui konservasi genetik. Konservasi genetik adalah salah satu cara dalam melestarikan suatu sumberdaya yang berkaitan dengan faktor genetik untuk mengurangi adanya resiko kepunahan. Menurut Frankham (2003), peran faktor genetik pada kepunahan populasi liar telah menjadi suatu kontroversi, namun beberapa bukti yang telah ada menunjukkan bahwa genetik berkontribusi penting untuk resiko kepunahan.

$P$. macrocephalus merupakan mamalia akuatik yang memiliki sifat highly migratory species dengan distribusi yang luas. Proses identifikasi berdasarkan marka molekuler dapat 
membantu dalam proses validasi kepastian dan keaslian spesies secara lebih akurat. Keberadaan nukleotida spesifik $P$. macrocephalus menjadi ciri spesifik pada spesies tersebut yang terdapat di Indonesia. Apabila terjadi illegal fishing atau illegal market, maka nukleotida spesifik padapenelitian ini menjadi barcode pada $P$. macrocephalus Indonesia dan dapat dijadikan sebagai biomarker.

\section{Kesimpulan}

Identifikasi berdasarkan sekuen basa nukleotida gen 16S rRNA parsial didapatkan kemiripan dengan Physeter catodon sebesar 99\%, dimana P. catodon merupakan sinonim dari $P$. macrocephalus. Pensejajaran sekuen nukleotida dengan outgroup (Balaenoptera physalus dan Balaena mysticetus) didapatkan nilai jarak genetik ketiga contoh dengan outgroup berkisar antara 0,0093-0,0726. Selain itu, didapatkan 25 nukleotida spesifik $P$. macrocephalus yang mampu membedakan dari spesies outgroup. Penelitian ini mampu memvalidasi spesies $P$. macrocephalus berdasarkan gen $16 \mathrm{~S}$ rRNA dan dapat dijadikan sebagai marka molekuler yang kuat untuk identifikasi P. macrocephalus.

\section{Daftar Pustaka}

[IUCN] International Union for Conservation of Nature and Natural Resources. 2015. The IUCN Red List of Threatened Species [Internet]. [diunduh 2015 Sep 15]. Tersedia pada: http://www.iucnredlist.org/details/41755/ 0 .

APEX Environmental. 2011. Indonesian Oceanic Cetacean Program [Internet]. [diunduh 2015 Sep 16]. Tersedia pada: http://www.apex- environmental.com/ ListIndonesia.html.

Alexander A, Steel D, Slikas B, Hoekzema K, Carraher C, Parks M, Cronn R, Baker CS. 2012. Low diversity in the mitogenome of sperm whales revealed by next-generation sequencing. Genome Biol. Evol. 5(1):113-129.

Arnason U, Gullberg A, Gretarsdottir S, Ursing B, Janke A. 2000. The mitochondrial genome of the sperm whale and a new molecular reference for estimating Eutherian divergence dates. $J$
Mol Evol. 50:569-578.

Baharum SN, Nurdalila AA. 2012. Application of $16 \mathrm{~S}$ rDNA and cytochrome $b$ ribosomal markers in studies of lineage and fish populations structure of aquatic species. Molecular Biology Report. 39:5225-5232.

Creese RG, Cole RG. 1995. Marine conservation in New Zealand. Pacific Conservation Biology. 2:55-63.

Desrianti F. 2011. Perubahan sosial masyarakat nelayan Lamalera (sudut pandang sosiologi ekonomi dan ekologi) [disertasi]. Bogor (ID): Institut Pertanian Bogor.

Frankham R. 2003. Genetics and Conservation Biology. Comptes Rendus Biologies. 326:S22-S29.

Gormley AM, Slooten E, Dawson SM, Barker RJ, Rayment WJ, DuFresne SD, Bräger S. 2012. First evidence that MPAs can work for marine mammals. Journal of Applied Ecology. 49(2):474-480.

Hebert PDN, Cywinska A, Ball SL, de Waard JR. 2003. Biological identifications through DNA barcodes. Proceedings of the Royal Society of London. 270:313322.

Hillis DM, Moritz C, Mable BK. 1996. Molecular Systematics. Massachusett: Sinauer Associates, Sunderland, Massachusett.

Hoyt E. 2005. Marine Protected Areas for

dfdfWhales, Dolphins and Porpoises. London: Earthscan.

Husson AM, LB Holthuis. 1974. Physeter macrocephalus Linnaeus, 1758, the valid name for the sperm whale. Zoologische Mededelingen. 48:205-217.

Jusuf M. 2001. Genetika I: Struktur dan Ekspresi Gen. Jakarta (ID): Sagung Seto.

Kreb D, Budiono. 2005. Cetacean diversity and habitat preferences in tropical waters of East Kalimantan, Indonesia. The Raffles Bulletin of Zoology 53(1):149155

Lazuardi ME, Christine H, dan Katherina T. 2011. Persepsi masyarakat di Kawasan Konservasi Laut Daerah Kabupaten Raja Ampat, Indonesia. Jakarta (ID): Conservation International (CI) Indonesia. 
Mitani T, Akane A, Tokiyasu T, Yoshimura S, Okii Y, Yoshida M. 2009. Identification of animal species using the partial sequences in the mitochondrial 16S rRNA gene. Legal Medicine. 11:S449-S450.

Notarbartolo di Sciara, G, Frantzis A, Bearzi, G. Reeves R. 2012. Physeter macrocephalus (Mediterranean subpopulation). The IUCN Red List of Threatened Species 2012: e.T16370739A16370477 [Internet]. [diunduh 2015 September 16] Tersedia pada: http://dx.doi.org/10.2305/IUCN. UK.2012-1.RLTS. T16370739A163704 77.en.

Ramadhan S. 2015. Pengelolaan sumber daya paus sperma (Physeter macrocephalus) berbasis Traditional Ecological Knowledge (TEK) di Lamalera, Nusa Tenggara Timur [skripsi]. Bogor (ID): Institut Pertanian Bogor.

Rice DW. 1989. Sperm whale-Physeter macrocephalus Linnaeus, 1758. Pp.177234, in Handbook of marine mammals; River dolphins and the larger toothed whales (SH Ridgway and R Harrison, eds.). Academic Press, London, 4:1-442.

Sanger F, Nicklen S, Coulson AR. 1977. DNA sequencing with chainterminating inhibitors. Proc Natl Acad Sci USA. 74:5463-5467.

Setiawan A. 2004. Sebaran tingkah laku Cetecea di perairan sekitar Taman Nasional Komodo, Flores, Nusa Tenggara Timur [skripsi]. Bogor (ID): Institut Pertanian Bogor.
Tamura K, Dudley J, Nei M, Kumar S. 2011. Mega 5: molecular evolutionary genetics analysis using maximum likelihood, evolutionary distance, and maximum parsimony methods. J Mol Biol Evol. 28(10):27312739.doi:10.1093/molbev/msr 121.

Taylor BL, Martinez M, Gerrodette T, Barlow J, Hrovat YN. 2007. Lessons from monitoring trends in abundance of marine mammals. Marine Mammal Science. 23.157-175.

Tomascik T, AJ Mah, Nontji, dan MK Moosa. 1997. The ecology of Indonesian seas. Singapore (SG): Periplus Edition .

Trivedi S, Aloufi AA, Ansari AA, Ghosh SK. 2015. Role of DNA barcoding in marine biodiversity assessment and conservation: An update. Saudi Journal of Biologica Sciences 23:161-171.

Tudge C. 2000. The Variety Of Life. New York (US): Oxford University Press.

Yusron E. 2012. Biodiversitas jenis Cetacean di Perairan Lamalera, Kupang, Nusa Tenggara Timur. Ilmu Kelautan. 17 (2):59-62. 